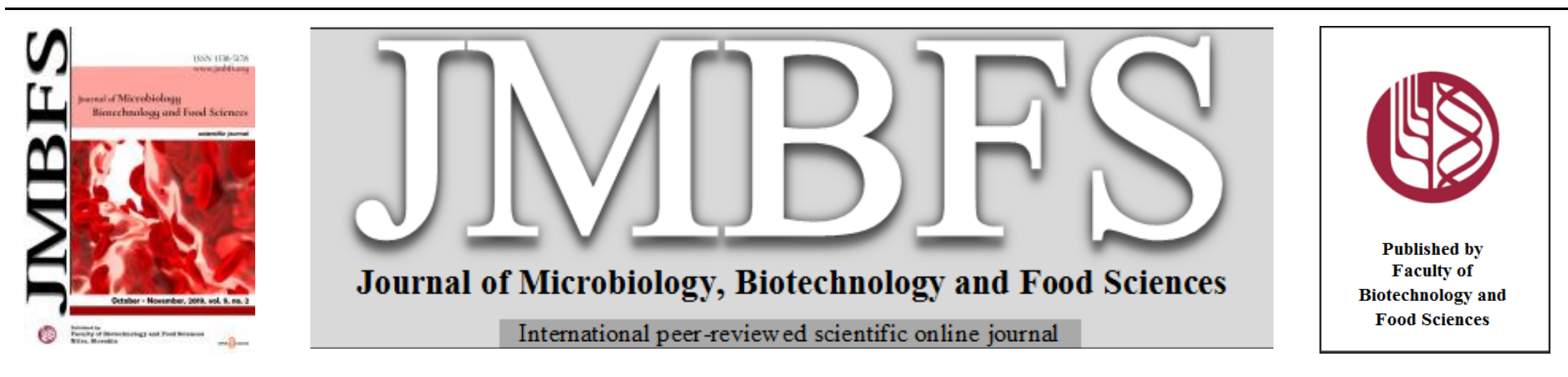

\title{
PURIFICATION AND CHARACTERIZATION OF NOVEL SOLVENT STABLE BACILLUS CEREUS PI-C4 PROTEASE FROM POULTRY WASTE
}

\author{
Parul Bhardwaj ${ }^{l}$, Saba Anjum ${ }^{l}$, Praveen Dahiya ${ }^{l} *$ \\ Address(es): \\ Centre for Biotechnology and Biochemical Engineering, Amity Institute of Biotechnology, Sector-125, Amity University Uttar Pradesh, Noida-201303, India.
}

*Corresponding author: pdahiya@ @amity.edu , praveen_sang@yahoo.com

doi: $10.15414 /$ jmbfs.2020.9.5.865-869

\section{ARTICLE INFO}

Received 16. 10. 2018

Revised 27. 9. 2019

Accepted 16. 10. 2019

Published 1. 4. 2020

Regular article

open $\partial_{\text {Access }}$

\begin{abstract}
A total of sixty-four bacterial isolates producing enzyme protease were isolated and screened from soil samples obtained from industries. A new potent solvent stable and alkaline protease producing isolate PI-C4 was isolated from Ghazipur Poultry waste site which was identified to be Bacillus cereus based on 16S rDNA sequence analysis. Consensus sequence of 1398 bp of the strain PI-C4 has been deposited in GenBank with accession number KM211501. Furthermore, the PI-C4 enzyme was subjected to precipitation using ammonium sulphate (70\% saturation), dialysis and was further concentrated by ion exchange chromatography which resulted in purification fold of 2.47 and $57.7 \%$ yield. The alkaline protease was found to be $46 \mathrm{kDa}$. Enzyme PI-C4 was also characterized with respect to temperature and $\mathrm{pH}$ and was found to be active at $\mathrm{pH} 9.0$ and $45^{\circ} \mathrm{C}$. The protease possesses significant stability $(64.7-82.2 \%)$ in the presence of surfactants tested. The alkaline protease possesses higher stability in solvent DMSO (107\%) followed by acetone (91\%) and isopropanol (82\%). The protease could therefore be useful for various applications like enzymatic leather treatment, feather degradation and recovery of silver.
\end{abstract}

Keywords: Alkaline protease; Bacillus cereus; Characterization; Purification; Solvent stable protease

\section{INTRODUCTION}

The proteases (EC 3:4, 11-19, 20-24, 99) are hydrolytic enzymes performing the role of catalyzing the peptide bonds and are found to be vital component of all life forms available on earth (Polgar, 1989). Proteases are ubiquitous and could be isolated from plant, animal and microbial sources. However, microbial protease with approx. $60 \%$ of worldwide sale of enzymes represents the largest group of industrial enzyme. Microbial proteases are an attractive source of enzymes due to the biochemical diversity, rapid rate of multiplication, easy cultivation and genetic manipulation in order to create new enzymes for diverse applicability (Rao et al., 1998). There is a considerable demand of microbial proteases due to their multifold applications in various industries like detergent, leather, food (meat tenderization, cheese-making, baking), pharmaceutical industry and bioremediation processes (Anwar \& Saleemuddin, 1998; Gupta $\boldsymbol{e t}$ al., 2002; Vijayalakshmi et al., 2011). However, the requirement of active preparation of enzymes for technological applications, microbial diversity and cost of proteases production continues the scope to search for newer proteases with desired selectivity and substrate tolerance.

Proteases are produced by microorganisms prevailing in soil, water samples and in highly alkaline environments including springs, industrial waters, soil from deserts and from decaying matters (Kanekar et al., 2011). Protease enzymes possess immense importance because of their much needed remarkable enzyme stability and activity at higher temperature and $\mathrm{pH}$. Although a number of fungi and bacteria from Aspergillus, Mucor, Rhizopus, Clostridium, Bacillus and Pseudomonas genus produced proteases, the prolific producer is genus Bacillus. Bacillus strains have the potential to secret higher level of enzyme proteases possessing significant proteolysis activity and wider range of stability (Kuberan et al., 2010; Ghasemi et al., 2011). As there is increase in demand and potential usefulness of Bacillus proteases for various applications, detailed screening needs to be carried out in samples collected from industries to get new sources of proteases with novel properties.

The present study includes the isolation of protease producing strain $\mathrm{C} 4$ from poultry waste site and its identification as Bacillus cereus PI-C4 secreting a solvent tolerant alkaline protease. This study also involves purification of the alkaline Bacillus protease and its characterization.

\section{MATERIAL AND METHODS}

\section{Collection of samples}

To isolate protease producing bacteria, soil samples were collected from various industries including poultry, leather, food industrial waste and slaughter house waste. The samples were collected in dry sterile poly bag according to microbiological procedures and were stored in the refrigerator $\left(4^{\circ} \mathrm{C}\right)$ for further experiments.

\section{Screening of isolated bacterial strains for protease production}

Soil samples collected were serially diluted and streaked on agar plates containing $0.1 \%$ peptone, $0.5 \% \mathrm{NaCl}, 2 \%$ agar with $10 \%$ skim milk. Protease producing isolates were screened and selected by observation of zone of clearance on skim milk plates by incubation of enzyme for $24-48$ hours at $37^{\circ} \mathrm{C}$ (Genkal \& Tari, 2006). Zone of hydrolysis surrounding the colony indicated the ability of isolate to produce protease and designated as the Proteolytics Index (PI). The Proteolitics Index was calculated by measuring the diameter of hydrolysis zone around the colony compared to diameter of the colony. The cultures were purified and preserved using $30 \%$ glycerol, further the culture was stored at $-70^{\circ}$ Celsius.

\section{Protease production}

Bacterial cultures screened positive for the production of enzyme protease using skim milk agar plates were grown in liquid media for protease assay. Inoculum was prepared using media containing nutrient broth $(\mathrm{w} / \mathrm{v})$ supplemented with beef extract $(0.3 \%)$, peptone $(0.5 \%)$, yeast extract $(0.2 \%)$ and sodium chloride (3\%) maintaining at $\mathrm{pH}-7.0$ for $18 \mathrm{~h}$ at $37^{\circ} \mathrm{C}$. After $18 \mathrm{~h}$ incubation, inoculum $(10 \%)$ was added to production medium. The production medium $(\mathrm{w} / \mathrm{v})$ containing glucose $(0.5 \%)$, peptone $(0.75 \%), \mathrm{MgSO}_{4} .7 \mathrm{H}_{2} \mathrm{O}(0.5 \%), \mathrm{KH}_{2} \mathrm{PO}_{4}$ $(0.5 \%), \mathrm{FeSO}_{4} .7 \mathrm{H}_{2} \mathrm{O}(0.01 \%), 37^{\circ} \mathrm{C}$ in a shaking incubator at $150 \mathrm{rpm}$ for $24 \mathrm{~h}$. Periodically, aliquots were withdrawn and the bacterial suspension was centrifuged for $10 \mathrm{~min}$ at $4^{0} \mathrm{C}$ at $10,000 \mathrm{rpm}$. Cell free supernatant was further used to measure protease activity at optimum conditions. 


\section{Assay for protease activity}

Enzyme activity from cell free culture supernatant was calculated by modified method (Takami et al., 1989). The mixture consists of $0.25 \mathrm{ml}$ of $1 \%$ casein in Tris- $\mathrm{Cl}$ buffer at $\mathrm{pH} 7.0$. To the mixture, protease enzyme $(0.25 \mathrm{ml})$ was added and incubated for ten minutes. Addition of $0.5 \mathrm{~mL}$ of TCA (trichloroacetic acid) will terminate the reaction. Subsequently, the reaction mixture was centrifuged for 10 minutes at $10,000 \mathrm{rpm}$. To the supernatant $(0.5 \mathrm{ml})$, add $2.5 \mathrm{ml}$ of $\mathrm{Na}_{2} \mathrm{CO}_{3}$ $(0.4 \mathrm{M})$ and $0.5 \mathrm{ml}$ of Folin- Ciocalteu's phenol reagent $(1: 1 \mathrm{v} / \mathrm{v})$. The absorbance at $660 \mathrm{~nm}$ was recorded using spectrophotometer. Tyrosine $(0-1000 \mathrm{mg} / \mathrm{L})$ was used as standard. One unit of protease may be defined as the amount of enzyme that could produce $1 \mu \mathrm{g}$ of tyrosine in 1 min under standard conditions of assay. Amount of protein available was calculated as per Lowry et al. (1951).

\section{Amplification of genomic DNA by 16S-rDNA}

In order to characterize protease-producing isolate at molecular level, Genomic DNA was extracted and purified as per the standard protocol (Sambrook $\boldsymbol{\&}$ Russell, 2001). The purity of the isolated DNA was assessed spectrophotometrically by the A260/A280 ratio. Amplification of $16 \mathrm{~S}$ rDNA gene fragment was done using PCR (polymerase chain reaction). 16S rRNA universal primers (for Forward and Reverse DNA sequencing) were used: the forward primer 27F (50-AGAGTTTGATCCTGGCT CAG-30) and the reverse primer 1492R (50-GGTTACCTTGTTACGACTT-30) utilizing BDT v3.1 Cycle sequencing kit on ABI 3730XL Genetic Analyzer. Using forward and reverse sequence data utilizing aligner software, consensus sequences of 1398 bp 16S rDNA gene was obtained. The 16S rDNA sequence obtained was utilized for carrying out BLAST (Altschul et al., 1997) of NCBI genbank database. Based on the maximum identity score obtained, first 10 sequences were selected and aligned by multiple alignment software program Clustal W. Ribosomal Database Project (RDB) was used to generate Distance matrix. Further, phylogenetic tree was constructed using MEGA 5 using the Neighbor-Joining method (bootstrap value of 1000). Obtained gene sequence was submitted to GenBank with the accession number KM211501.

\section{Protease purification steps}

The selected culture for protease production was grown for $32 \mathrm{~h}$ in the production media and centrifugation was done at $10,000 \mathrm{rpm}$ for $10 \mathrm{~min}$ at $4^{\circ} \mathrm{C}$ to harvest the cells. The obtained supernatant $(100 \mathrm{ml})$ was fractionated by precipitation with ammonium sulfate between $50 \%$ and $70 \%$ of saturation maintaining the temperature at $4^{0} \mathrm{C}$ for all subsequent steps. The solution obtained was centrifuged at $10,000 \mathrm{rpm}$ for 20 min maintaining the temperature at $4^{0} \mathrm{C}$. Precipitate obtained was collected which was further dissolved using $0.01 \mathrm{M}$ phosphate buffer at $\mathrm{pH}$ 7. The collected solution was further dialyzed at $4^{0} \mathrm{C}$ for $10 \mathrm{~h}$.

Further the protease extract was purified through an ion exchanger DEAEcellulose column. The DEAE-cellulose column $(2.5 \times 70 \mathrm{~cm})$ used was preequilibrated using potassium phosphate buffer $(20 \mathrm{mM})$ at $\mathrm{pH}$ 7. Proteins bound were further eluted with phosphate buffers at room temperature. All the fractions obtained were checked for proteolytic assay using skim milk-agar plates Fractions with significantly higher protease activity were collected together and then lyophilized. The protein was analyzed by Lowry $\boldsymbol{e t}$ al. (1951) using BSA as standard protein.

\section{Characterization of PI -C4 Protease}

\section{Effect of $\mathrm{pH}$ and temperature}

Temperature and $\mathrm{pH}$ stability profiles and optimum values were analyzed in the range of pH 6.0 to 11.0 using different activity buffers at $37^{\circ} \mathrm{C}$. The buffers used includes: Phosphate ( $\mathrm{pH}$ 6.0), Tris- $\mathrm{HCl}(\mathrm{pH} 7.0-9.0)$ and Carbonate-bicarbonate $(\mathrm{pH} 10.0-11.0)$. The influence of temperature on protease activity was examined by performing the assay at a temperature range of 30 to $70^{\circ} \mathrm{C}, \mathrm{pH} 8.0$ utilizing substrate casein. Relative activities (in \%) were expressed as a percentage of the activity of the untreated control taken as $100 \%$.

\section{Effect of surfactants}

The effect of surfactants on the stability of enzyme was examined by incubating the mixture of enzyme with each surfactant for $1 \mathrm{~h}$. The surfactants tested includes: SDS, Triton X 100 and Tween 80 . After incubation for $1 \mathrm{~h}$ with surfactant, the residual enzyme activity $(\%)$ was analyzed. The protease without adding the surfactants was calculated and was considered as $100 \%$ (control).

\section{Organic solvent stability of PI-C4}

Organic solvent stability of PI-C4 protease enzyme was determined in the presence of various organic solvents. It includes acetone, ethanol, methanol, chloroform, ethyl acetate, isopropanol, toluene and dimethyl sulfoxide (DMSO).
Equal volume $(0.1 \mathrm{ml})$ of obtained protease and organic solvent was incubated together for $1 \mathrm{~h}$ at $30^{\circ} \mathrm{C}$. Further, residual activity (\%) was measured. The protease activity devoid of organic solvent was calculated and was considered as $100 \%$ (control).

\section{RESULTS}

\section{Isolation and Identification of Protease secreting Bacterial Strains}

Altogether 64 bacterial isolates were obtained from soil samples collected from various industries. All the bacterial isolates obtained were tested on skim milk agar plates. Among the isolates screened, the isolate PI-C4 possessed maximum zone of hydrolysis seen on skim milk agar plates, confirming it to be significan protease producing isolate. Purity of isolate was ascertained through repeated streaking. The PI-C4 isolate was subsequently identified to be Bacillus cereus as predicted by $16 \mathrm{~S}$ rDNA studies. Bacillus cereus $\mathrm{PI}-\mathrm{C} 4$ produces a clearance zone of $10 \mathrm{~mm}$ diameter, indicating the production of protease. The proteolytic activity was established using casein $(1 \%)$ as substrate.

\section{Strain Identification by 16S rDNA Sequencing}

Morphological, biochemical characterization and 16S rDNA sequencing of the isolate indicated it to be Bacillus cereus. Genomic DNA was extracted and purified as per the standard protocol. Quality was evaluated on 1.2\% Agarose gel, a single band of high-molecular weight DNA has been observed. Fragment of $16 \mathrm{~S}$ rDNA gene was amplified by PCR from the above isolated DNA. A single discrete PCR amplicon band of $1500 \mathrm{bp}$ was observed (Fig. 1). The PCR amplicon obtained was purified and further processed for the sequencing. By studying the BLAST alignment tool of the 16S rDNA gene sequence for isolated microbe by using a combination of NCBI GenBank and RDP database, a close association of PI-C4 isolate was confirmed with Bacillus sp. For identification of the isolate, the $16 \mathrm{~S}$ rDNA sequencing was performed. Isolate PI-C4 was found to possess similarity to Bacillus cereus strain C11C (Gen Bank Accession No HQ388817.1) based on the phylogenetic analysis and nucleotide homology. Around $99 \%$ homology was observed with that of other Bacillus cereus strains including Bacillus cereus strain LD147 (NCBI Accession No KJ534434.1), Bacillus cereus strain JD15 (NCBI Accession No KJ534430.1) etc. Consensus sequence of $1398 \mathrm{bp}$ of the strain PI-C4 has been submitted (GenBank) with accession number KM211501. On the basis of results obtained, PI-C4 was confirmed to be Bacillus cereus. Further, sequences obtained were aligned in order to construct phylogenetic tree by neighbor-joining method is shown in fig. 2. The PI-C4 strain identified will be subsequently used for purification studies.

1

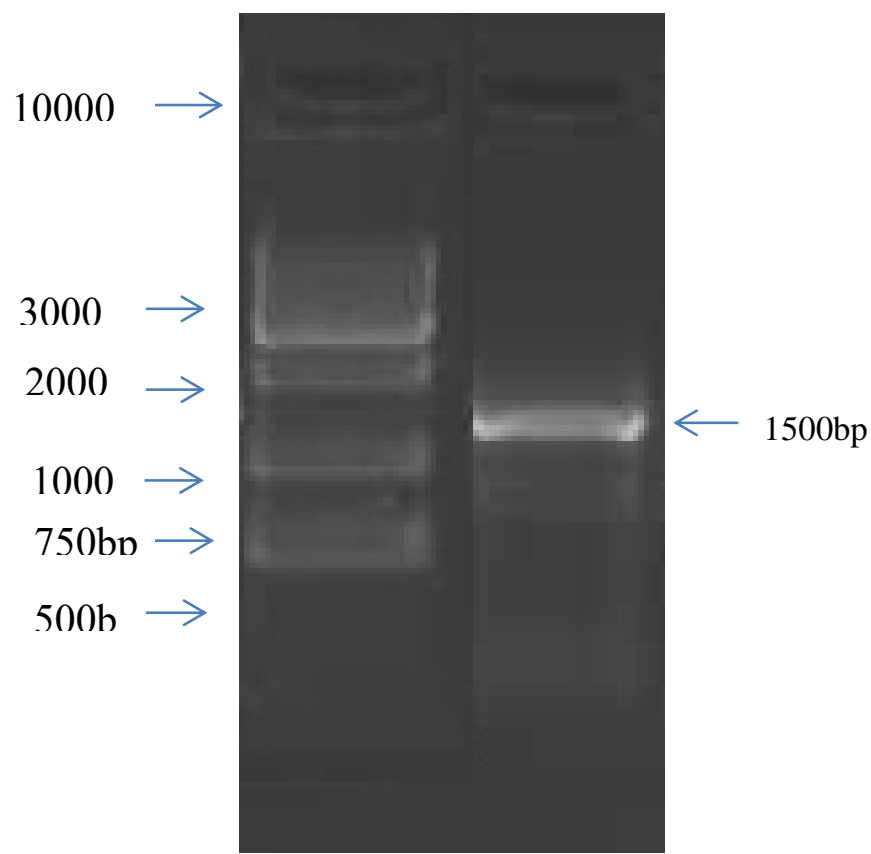

Figure $11.2 \%$ Agarose gel showing single $1.5 \mathrm{~kb}$ and $16 \mathrm{~S}$ rDNA amplicon band Lane 1: $1 \mathrm{~kb}$ Ladder Lane 2: 16S rDNA amplicon 


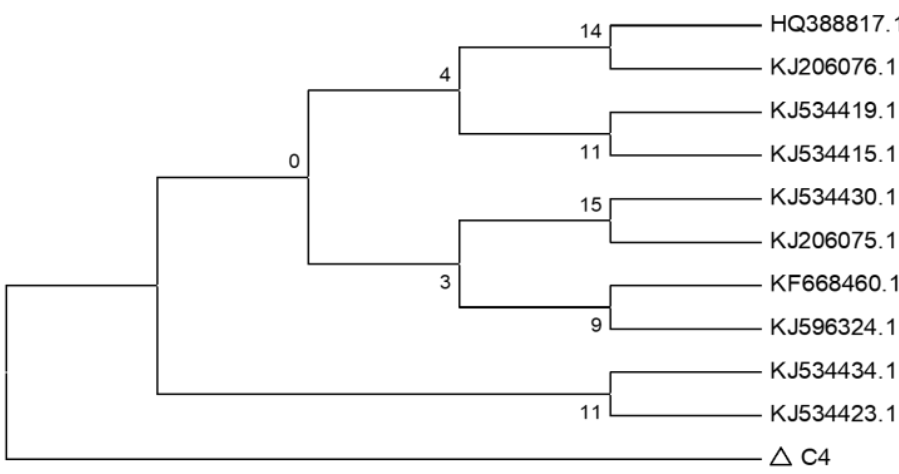

Figure 2 Phylogenetic tree of protease obtained from Bacillus cereus based on 16S DNA gene sequences.

\section{Purification of Bacillus cereus protease}

Bacillus cereus $\mathrm{PI}-\mathrm{C} 4$ strain produced extracellular alkaline protease which was harvested after $32 \mathrm{hrs}$ of growth in production medium. Crude protease obtained was precipitated using ammonium sulphate precipitation (70\%) followed by its dialysis against $0.01 \mathrm{M}$ phosphate buffer at $\mathrm{pH} 7.0$ (table 1). After ammonium sulphate fractionation, the protease was purified to 1.25 -folds and $61.21 \%$ of yield. Further purification of the protease was done using DEAE- cellulose column which resulted in 2.47 -folds purification. The molecular weight of the protease was found to be $46 \mathrm{kDa}$ by SDS-PAGE.

Table 1 Protease purification profile from alkaline Bacillus cereus PI-C4

\begin{tabular}{lccccc}
\hline Purification & Total & Total & Specific & Yield & Purification \\
Steps & Protein & activity & activity & $(\%)$ & fold \\
& $(\mathbf{m g})$ & $(\mathrm{U})$ & $(\mathrm{U} / \mathbf{m g})$ & & \\
\hline
\end{tabular}

\section{Culture}

supernatant

$(\mathrm{NH} 4)_{2} \mathrm{SO}_{4}$

precipitation

$$
4.3
$$

(70\%

2.1

3589

1709

61.2

saturation) and

0.8

3385

4231

57.7

dialysis

DEAE cellulose

chromatography

\section{Characterization of Bacillus cereus $\mathrm{PI}-\mathrm{C} 4$ protease}

\section{pH studies of Bacillus cereus PI-C4 protease}

The extracellular protease obtained from Bacillus cereus PI-C4 was analyzed with respect to $\mathrm{pH}$ and temperature optimum and stability where casein was used as a substrate. Protease activity and stability profile were evaluated in wide range of $\mathrm{pH}$ under standard conditions. Bacillus cereus protease was found to be active in the $\mathrm{pH}$ range of $7.0-10.0$. (fig. 3 ) and optimum enzyme activity was obtained at $\mathrm{pH} 9$, confirming it to be an alkaline protease. Drastic drop in protease activity was observed on either side of the peak. Stability of protease enzyme in various $\mathrm{pH}$ activity buffers was also analyzed. The protease PI-C4 was found to possess moderate stability (62 per cent stability) between $\mathrm{pH} 8.0-10.0$ with 100 per cent stability at $\mathrm{pH} 9.0$ (fig. 3).

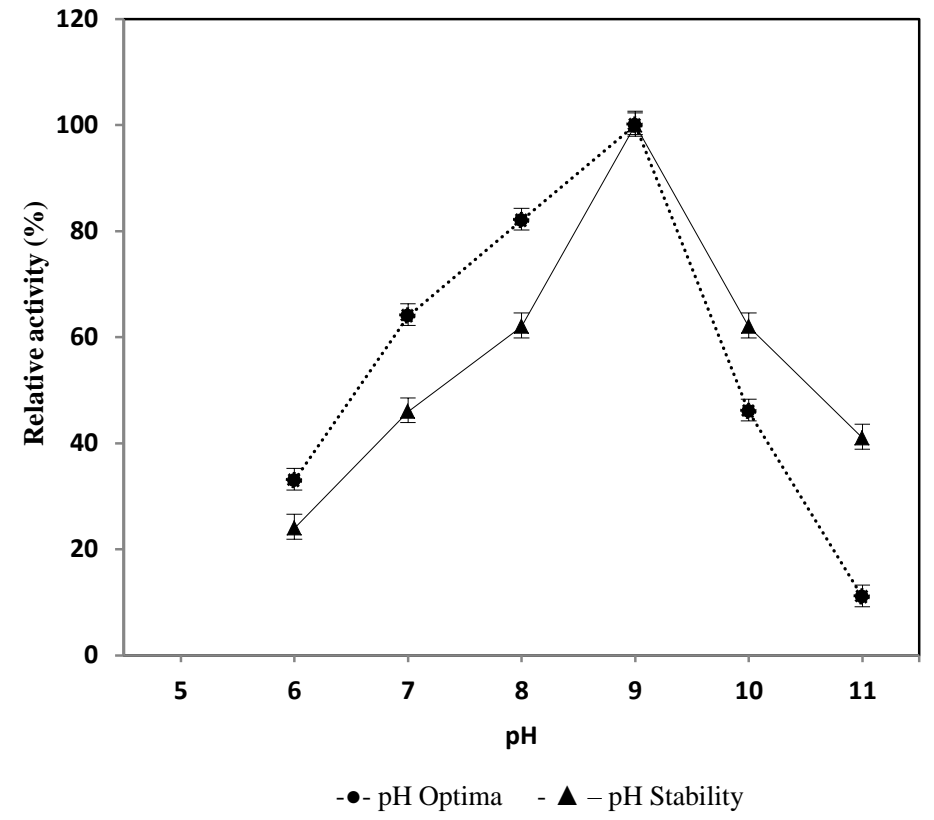

Protease activity tested using different activity buffers: Phosphate ( $\mathrm{pH}$ 6.0), Tris- $\mathrm{HCl}(\mathrm{pH}$ 7.0-9.0) and Carbonate-bicarbonate

(pH 10.0-11.0).

Figure $3 \mathrm{pH}$ effecting the activity and stability of protease from Bacillus cereus PI-C4

\section{Temperature studies of Bacillus cereus PI-C4}

Temperature studies for Bacillus cereus PI-C4 protease enzyme were studied. The protease enzyme was incubated at different temperature in the range of $30^{\circ} \mathrm{C}$ $-70^{\circ} \mathrm{C}(\mathrm{pH} 9.0)$ and relative activity was calculated. Under otherwise the same condition as in the standard method for enzyme activity assay, the enzyme exhibits optimum protease activity at $45^{\circ} \mathrm{C}$ and was found to retain significan protease activity obtained in between $35^{\circ} \mathrm{C}$ and $50^{\circ} \mathrm{C}$. Increase in the temperature to $70^{\circ} \mathrm{C}$ resulted in no activity (fig. 4 ).

To analyze the temperature stability of protease, the protease was incubated in the reaction mixture at varied temperature between $35^{\circ} \mathrm{C}-55^{\circ} \mathrm{C}$ for 1 hour at $\mathrm{pH}$ 9.0. By analyzing the thermal stability, the protease was analyzed to be a stable protease possessing stability up to $40^{\circ} \mathrm{C}$ till 1 hour. Significant loss in activity was observed when the temperature was increased further. The enzyme was found to exhibit low stability at $50^{\circ} \mathrm{C}$ and $55^{\circ} \mathrm{C}$ retaining only $43 \%$ and $11 \%$ relative activity respectively after $1 \mathrm{~h}$ of incubation as shown in fig. 5 .

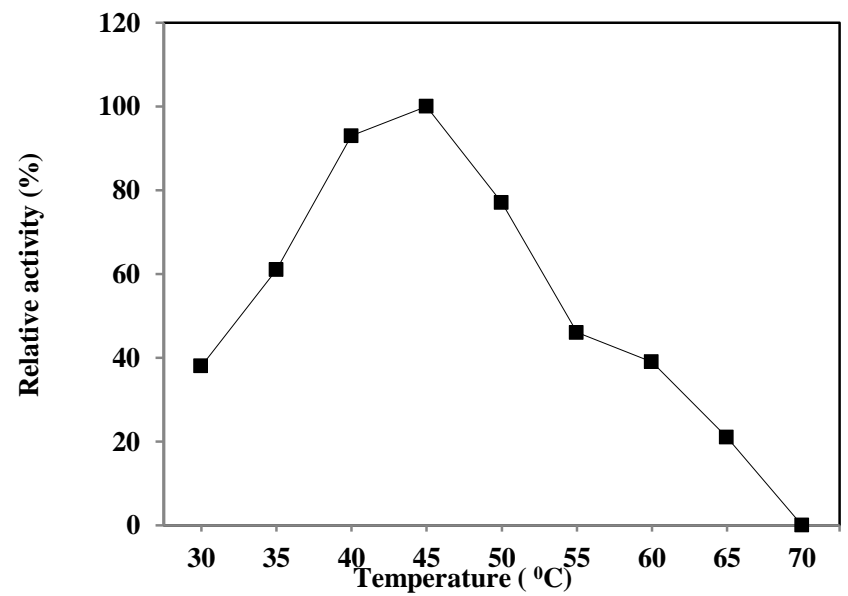

Protease activities were examined at $\mathrm{pH} 8.0$ in between a temperature of $30-70^{\circ} \mathrm{C}$ utilizing substrate casein.

Figure 4 Temperature optima of protease from Bacillus cereus PI-C4. 


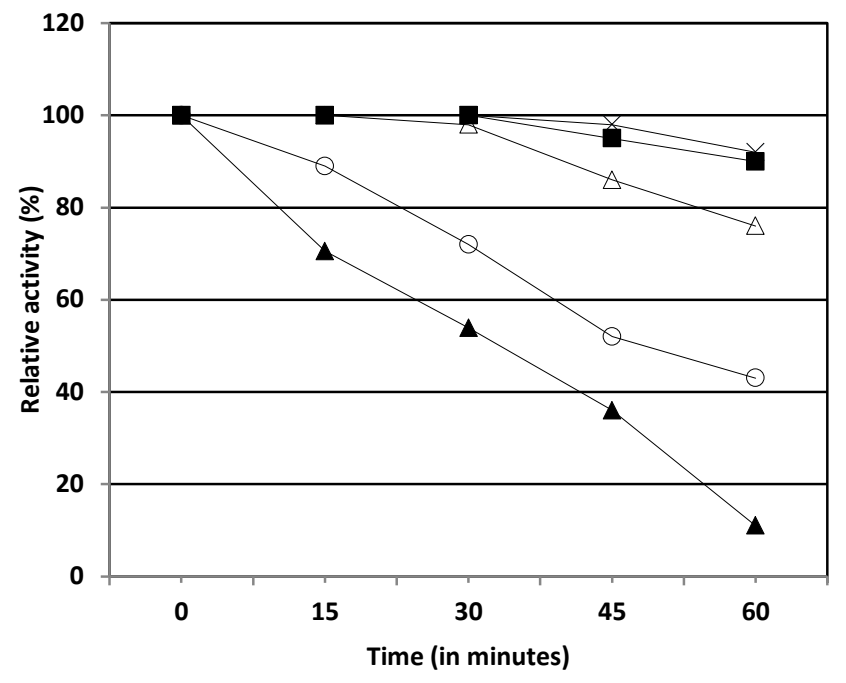

$\times 35^{\circ} \mathrm{C}-40^{\circ} \mathrm{C} \triangle 45^{\circ} \mathrm{C} \bigcirc 50^{\circ} \mathrm{C} \longrightarrow 55^{\circ} \mathrm{C}$

Figure 5 Temperature stability profile for protease from Bacillus cereus $\mathrm{PI}-\mathrm{C} 4$ Protease activities were examined at different temperatures $\left(35-55^{\circ} \mathrm{C}\right)$ after regular intervals for 1 hour.

\section{Effect of surfactants}

The enzyme protease was found to be significantly stable when incubated in the various surfactants tested like TritonX-100, SDS and Tween 80 (table 2). Maximum stability was observed in SDS, followed by surfactant Tween 80 and Triton $\mathrm{X}-100$ by $82.2,69.3$ and $64.7 \%$ respectively.

\section{Protease stability in organic solvents}

The stability of Bacillus cereus protease enzyme was analyzed with different organic solvents incubated at $30^{\circ} \mathrm{C}$ for $1 \mathrm{~h}$ (Table 3 ). Protease PI-C4 was found to possess significant stability in all the solvents tested and found to retain higher than $60 \%$ of activity. Higher stability of the protease enzyme was obtained in the case of solvent DMSO (107\%) which is followed by acetone and isopropanol by 101 and $98 \%$ respectively.

Table 2 Surfactants effect on protease activity from Bacillus cereus PI-C4

\begin{tabular}{lll}
\hline Surfactant & Concentration (\%) & Residual activity* (\%) \\
\hline Control & - & 100 \\
SDS & 0.5 & $82.2 \pm 2.5$ \\
Tween 80 & 1 & $69.3 \pm 0.74$ \\
Triton X-100 & 1 & $64.7 \pm 0.93$ \\
\hline
\end{tabular}

* The means of three experiments done and the residual activity is expressed as mean $\pm \mathrm{SD}$.

Table 3 Organic solvents effects on protease activity from Bacillus cereus PI-C4

\begin{tabular}{ll}
\hline Organic Solvents & Residual activity* (\%) \\
\hline Control & 100 \\
Ethanol & $76 \pm 1.6$ \\
DMSO & $107 \pm 2.5$ \\
Isopropanol & $98 \pm 2.3$ \\
Methanol & $61 \pm 1.8$ \\
Acetone & $101 \pm 1.6$ \\
Chloroform & $63 \pm 1.3$ \\
Toluene & $91 \pm 2.1$ \\
Ethyl acetate & $82 \pm 2.7$
\end{tabular}

* The means of three experiments done and the residual activity is expressed as mean \pm SD.

\section{DISCUSSION}

The present investigation includes the isolation of several protease producing bacterial isolates. For isolation various soil samples were collected from differen industries in Noida, India. Amongst the isolates screened, the isolate PI-C4 was found to be best producer as it possesses largest zone of clearance on skim milk agar medium. Identification of the strain was done by $16 \mathrm{~S}$ rDNA sequencing and identified as Bacillus cereus. The sequence of strain PI-C4 was similar to Bacillus cereus strain $\mathrm{C} 11 \mathrm{C}$ based on nucleotide homology and phylogenetic analysis. Similarly, various researchers through $16 \mathrm{~S}$ rDNA sequencing and analysis were able to characterize and identify novel strains (Zambare $\boldsymbol{e t} \boldsymbol{a l}$. 2011; Waghmare et al., 2015). Analysis by 16S rDNA is not providing highly genuine identification and is not providing clear cut differences in between the closely related Bacillus sp. like Bacillus subtilis, Bacillus cereus, Bacillus licheniformis etc., but the data can be utilized for establishing preliminary relatedness (Saxena $\boldsymbol{e t}$ al., 2014). Isolate selected was identified to be Bacillus sp. based on the $16 \mathrm{~S}$ rDNA sequence that includes blasting it against the databases available like NCBI and RDP. Finally, MEGA 5 was used to construct the phylogenetic tree.

Further, the purification of protease was done by ammonium sulphate precipitation followed by dialysis and column chromatography using DEAE cellulose column resulting in 2.47-folds purification. Similar results were reported where 1.92- folds purification was obtained by a method involving ammonium sulphate precipitation, ultra-filtration, lyophilization and dialysis as observed by Naidu, 2011. Liang et al. (2012) reported 332-folds purification for Bacillus cereus TKU022. The molecular weight was analyzed by SDS-PAGE which was found to be $46 \mathrm{kDa}$. Similarly, B. cereus TKU022 (Liang et al., 2012) protease was reported to be $45 \mathrm{kDa}$. Mostly the enzyme protease obtained from Bacillus species are found to be in between 20 and $38 \mathrm{kDa}$. However, some proteases possessing high molecular weight are also recovered from $B$. subtilis and B. pseudofirmus SVB1 (Anbu, 2013).

The purified enzyme from Bacillus cereus PI-C4 was found to have maximum activity and stability at alkaline $\mathrm{pH}$. Similar results were reported by various workers for B. subtilis AP MSU6 (Maruthiah et al., 2013), B. mojavensis A21 (Haddar et al., 2009) and B. subtilis GACAS8 (Kumar et al., 2015). The alkaline protease showed $45^{\circ} \mathrm{C}$ as an optimum temperature and found to possess $100 \%$ stability up to $40^{\circ} \mathrm{C}$ for $1 \mathrm{~h}$. Further increase in the temperature results in significant loss of activity. Proteases reported from various Bacillus species were found to possess temperature optima and stability in the range of $30-50^{\circ} \mathrm{C}$ as in case of B. licheniformis (Sareen \& Mishra, 2008), Bacillus thermoruber (Manachini et al., 1988), Bacillus cereus SIU1 (Singh et al., 2012) and B. clausii (Joo et al., 2003). Whereas, few thermophilic Bacillus proteases possess higher optimum and stability temperatures of $50^{\circ} \mathrm{C}$ or above as reported for Bacillus cereus strain AT by Vijayaraghavan et al. (2014) and Bacillus licheniformis RP1 by Kamoun et al. (2008).

For industrial applications, the isolated protease should not only possess higher activity and stability at different temperatures and $\mathrm{pH}$, but should also have moderate to higher stability in surfactants and organic solvents. Bacillus cereus PI-C4 protease possess significant stability $(64.7-82.2 \%)$ in the presence of surfactants. Similarly, Satishkumar et al. (2015), Haddar et al. (2009) and Shah et al. (2010) observed the stability of protease in different detergents in case of Bacillus subtilis GACAS8, B. mojavensis A21and B. cereus were incubated with TritonX-100, SDS and Tween 80 . In contrary, very high relative activity (96-113\%) was reported in Brevibacillus sp. strain AS-S10-II (Rai \& Mukherjee, 2011).

Solvent stable proteases have immense applications in various industries. The protease from Bacillus cereus $\mathrm{PI}-\mathrm{C} 4$ possesses moderate to high stability in the organic solvents tested (from 61 to 107\%). Similarly, few scientists have reported highly stable proteases in different hydrophilic organic solvents in case of Bacillus koreensis (Anbu, 2013) and S. maltophilia strain SK (Waghmare et al., 2015). Organic solvent stable proteases have immense applications, the most important being its utilization for biocatalysis in organic solvents for synthesis of peptides. The protease showing stability against denaturation or unfolding which may be because of the disulfide bonds present (Najafi et al., 2005)

\section{CONCLUSION}

The present investigation includes isolation of Bacillus cereus PI-C4 protease from poultry waste site soil sample possessing higher content of protein, capable of secreting extracellular protease enzyme active at alkaline $\mathrm{pH}$ and higher temperatures. The purified protease from Bacillus cereus PI-C4 showed significant stability at temperature of $45^{\circ} \mathrm{C}$ and at $\mathrm{pH}$ 9. The protease was found to be compatible with various ionic and non-ionic detergents and organic solvents tested. Considering the important characteristics of isolated extracellular protease from Bacillus cereus PI-C4 with respect to temperature, $\mathrm{pH}$ and solvents tested, the protease could be exploited for its application in the field of feather degradation, processing of leather and recovery of silver from used X-Ray film. 
Acknowledgements: The authors are thankful to Amity Institute of Biotechnology, Amity University, Noida, U.P, India for providing infrastructural facilities to carry out this study successfully.

\section{REFERENCES}

Altschul, S.F., Madden, T.L., Schaffer, A.A. .....\& Zhang. J. (1997). Gapped BLAST and PSI-BLAST: a new generation of protein database search programs. Nucleic Acids Research, 25, 3389-3402.

Anbu, P. (2013). Characterization of solvent stable extracellular protease from Bacillus koreensis (BK-P21A). Int J Biological Macromol, 56, 162-168. https://doi.org/10.1016/j.ijbiomac.2013.02.014

Anwar, A. \& Saleemuddin, A. (1998). Alkaline proteases: A review. Bioresource Technol, 64, 175-183. https://doi.org/10.1016/S0960-8524(97)00182-X

Genkal, H. \& Tari, C. (2006). Alkaline protease production from alkalophilic Bacillus sp., isolated from natural habitats. Enzyme and Microbial Technol, 39, 703-710. https://doi.org/10.1016/j.enzmictec.2005.12.004

Ghasemi, Y.Y., Rasoul-Aminia, S., Ebrahiminezha, A....\& Kazemi, A. (2011) Screening and isolation of extracellular protease producing bacteria from the Maharloo salt lake. Iranian J Pharmaceut Sci, 7(3), 175-180.

Gupta, R., Beg, Q.K. \& Lorenz, P. (2002). Bacterial alkaline proteases: molecular approaches and industrial applications. Appl Microbiol Biotechnol, 59, 15-20. https://doi.org/10.1007/s00253-002-0975-y

Haddar, A., Agrebi, R., Bougatef, A.....\& Hmidet, N. (2009). Two detergen stable alkaline serine-proteases from Bacillus mojavensis A21: purification, characterization and potential application as a laundry detergent additive Bioresource Techn, 13, 366-373. https://doi.org/10.1016/j.biortech.2009.01.061

Joo, H.S., Kumar, C.G., Park, G.C...\& Paik, S.R. (2003). Oxidant and SDS stable alkaline protease from Bacillus clausii I-52: production and some properties. J Appl Microbiol, 95(2), 267-272.

Kanekar, P.P., Nilegaonkar, S.S., Sarnaik, S.S. \& Kelkar, A.S. (2002) Optimization of proteases activity of alkaliphilic bacteria isolated from an alkaline lake in India. Bioresource Technol, 85(1), 87-93.

Kuberan, T., Sangaralingam, S. \& Thirumalai, V.A. (2010). Isolation and optimization of protease producing bacteria from halophilic soil. J Biol Sci Res l(3), 163-174.

Kumar, R.S., Gnanakkan, A. \& Jeganathan, A. (2015). Production, purification and characterization of alkaline protease by ascidian associated Bacillus subtilis GACAS8 using agricultural wastes. Biocatal and Agri Biotechnol, 4, 214-220. https://doi.org/10.1016/j.bcab.2014.12.003

Liang, T.W., Hsieh, J.L. \& Wanga, S.L. (2012). Production and purification of a protease, a chitosanase, and chitin oligosaccharides by Bacillus cereus TKU022 fermentation. Carbohydrate Res, 362, 38-46. https://doi.org/10.1016/j.carres.2012.08.004

Lowry, O.H., Rosebrough, N.J., Farr, A.L. \& Randall, R.J. (1951). Protein measurement with the Folin phenol reagent. J Biol Chem, 93(1), 265-275. Manachini, P.L., Fortina, N.G. \& Parini, C. (1988). Thermostable alkaline protease produced by Bacillus thermoruber- a new species of Bacillus. Appl Microbiol Biotechnol, 28, 409-413. https://doi.org/10.1007/BF00268205

Maruthiah, T., Esakkiraj, P., Prabakaran, G.....\& Palavesam, A. (2013). Purification and characterization of moderately halophilic alkaline serine protease from marine Bacillus subtilis AP-MSU6. Biocatal Agric Biotechnol, 2, 116-119. https://doi.org/10.1016/j.bcab.2013.03.001

Naidu, K.S. (2011). Characterization and purification of protease enzyme. $J A p p l$ Pharmaceutical Sci, 1(3), 107-112.

Najafi, M.F., Depbagkar, D. \& Depbagkar, D. (2005). Potential application of protease isolated from Pseudomonas aeruginosa PD100. Electronic Biotechnol, 8, 197-203.

Polgar, L., 1989. Mechanisms of protease action. CRC Press, Inc, Boca Raton, Florida.

Rai, S.K.\& Mukherjee, A.K. (2011). Optimization of production of an oxidan and detergent-stable alkaline keratinase from Brevibacillus sp. strain AS-S10-II: Application of enzyme in laundry detergent formulations and in leather industry. Biochem Engg J, 54, 47-56.

Rao, M.B., Tanksale, A.M., Ghatge, M.S. \& Deshpande, V.V. (1998). Molecular and biotechnological aspects of microbial proteases. Microbiol Mol Biol Rev, 2(3), 597-635

Sambrook, J., Russell, D. (2001). Molecular Cloning: A laboratory manual, Cold Spring Harbor Lab. Press, New York.

Sareen, R. \& Mishra, P. (2008). Purification and characterization of organic solvent stable protease from Bacillus licheniformis RSP-09-37. Appl Microbiol Biotechnol 79(3), 399-405. https://doi.org/10.1007/s00253-008-1429-y

Saxena, S., Verma, J. \& Modi, D.R. (2014). RAPD-PCR and 16S rDNA phylogenetic analysis of alkaline protease producing bacteria isolated from soil of India: Identification and detection of genetic variability. J Genetic Engg and Biotechnol, 12, 27-35. https://doi.org/10.1016/j.jgeb.2014.03.001

Sellami-Kamoun, A., Haddar, A., Ali, N.E.H., Ghorbel-Frikha, B....\& Kanoun, S. (2008). Stability of thermostable alkaline protease from Bacillus licheniformis RP1 in commercial solid laundry detergent formulations. Microbiological Res 163, 299-306. https://doi.org/10.1016/i.micres.2006.06.001
Shah, K., Mody, K., Keshri, V. \& Jha, B. (2010). Purification and characterization of a solvent, detergent and oxidizing agent tolerant protease from Bacillus cereus isolated from the Gulf of Khambhat. J Molecular Catal B Enzyme, 67, 85-91. https://doi.org/10.1016/j.molcatb.2010.07.010

Singh, S.K., Singh, S.K., Tripathi, V.R. \& Garg, S.K. (2012). Purification, characterization and secondary structure elucidation of a detergent stable, halotolerant, thermoalkaline protease from Bacillus cereus SIU1. Process Biochem, 47, 1479-1487. https://doi.org/10.1016/j.procbio.2012.05.021

Takami, H., Akiba, T. \& Horikoshi, A. (1989). Production of extremely thermostable alkaline protease from Bacillus sp. no. AH-101. Appl Microbiol Biotechnol, 30, 120-124. https://doi.org/10.1007/BF00263997

Vijayalakshmi, S., Venkatkumar, S. \& Thankamani, V. (2011). Screening of alkalophilic thermophilic protease isolated from Bacillus RV.B2.90 for industrial applications. Res in Biotechnol, 2(3), 32-41.

Vijayaraghavan, P., Lazarus, S., Samuel, V. \& Prakash, G. (2014). De-hairing protease production by an isolated Bacillus cereus strain AT under solid-state fermentation using cow dung: Biosynthesis and properties. Saudi J Biological Sci, 21, 27-34. https://doi.org/10.1016/j.sibs.2013.04.010

Waghmare, S.R., Gurav, A.A., Mali, S.A....\& Nadaf, N.F. (2015). Purification and characterization of novel organic solvent tolerant $98 \mathrm{kDa}$ alkaline protease from isolated Stenotrophomonas maltophilia strain SK. Protein Exp Purifi, 107 1-6. https://doi.org/10.1016/i.pep.2014.11.002

Zambare, V., Nilegaonkar, S. \& Kanekar, P. (2011). A novel extracellular protease from Pseudomonas aeruginosa MCMB-327: Enzyme production and its partial characterization. New Biotechnol, 28(2), 173-181. https://doi.org/10.1016/j.nbt.2010.10.002 